Nacar, R., Özdemir, K. (2021). “E-Ticaret Pazaryeri Web Sitelerinin Dinamikleri: Covid-19 Pandemi Sürecindeki Değişim", Eskişehir Osmangazi Üniversitesi iiBF Dergisi, 16(1), 205 - 226.

Doi: 10.17153/oguiibf.867263

Başvuru: 24.01.2021

Kabul:10.03.2021

Araştırma Makalesi/Research Article

\title{
E-Ticaret Pazaryeri Web Sitelerinin Dinamikleri: Covid-19 Pandemi Sürecindeki Değişim ${ }^{1}$
}

\begin{tabular}{|c|c|c|}
\hline \multicolumn{2}{|c|}{$\begin{array}{l}\text { E-Ticaret Pazaryeri Web Sitelerinin Dinamikleri: Covid- } \\
19 \text { Pandemi Sürecindeki Değişim }\end{array}$} & $\begin{array}{l}\text { Dynamics of E-Commerce Marketplace Websites: Shift } \\
\text { in Covid-19 Pandemic }\end{array}$ \\
\hline \multirow{2}{*}{\multicolumn{2}{|c|}{$\begin{array}{l}\text { Öz } \\
\text { Bu çalışma e-ticaret pazaryeri web sitelerine ait değiş- } \\
\text { kenler arasındaki ilişkileri ve Covid-19 pandemisinin söz } \\
\text { konusu ilişkilere etkisini analiz etmektedir. Araştırmanın } \\
\text { örneklemi olan } 16 \text { e-ticaret pazaryeri web sitesinin Co- } \\
\text { vid-19 pandemisinin farklı dönemlerine (Şubat-Mayıs- } \\
\text { Ekim 2020) ait ikincil verileriyle geliştirilen model ve hi- } \\
\text { potezler kanonik korelasyon analiziyle test edilmiştir. } \\
\text { Çalışma sonucunda bağımsız değişkenler seti (web sitesi } \\
\text { teknik özellikleri, siteye giriş kaynakları ve sosyal medya } \\
\text { kullanımı) ile bağımlı değişkenler seti (web sitesi kulla- } \\
\text { nım istatistikleri) arasında güçlü ilişki olduğu ve bu ilişki- } \\
\text { nin farklı aylar itibariyle tekrarladığı bulgusuna ulaşımış- } \\
\text { tır. Ayrıca, incelenen aylarda farklı web sitesi özellikleri- } \\
\text { nin öne çıktığı ve değişkenler arası ilişki yapısının pan- } \\
\text { demi sürecinde değiştiği görülmektedir. }\end{array}$}} & Abstract \\
\hline & & $\begin{array}{l}\text { This study investigates the relations between variables } \\
\text { of e-commerce marketplace websites and the effect of } \\
\text { the Covid-19 pandemic on those relations. Based on the } \\
\text { secondary data of } 16 \text { e-commerce marketplace web- } \\
\text { sites for different periods of the Covid-19 pandemic } \\
\text { (February-May-October 2020), a model and hypotheses } \\
\text { were tested with canonical correlation analysis. It was } \\
\text { found that there is a strong relationship between the in- } \\
\text { dependent variable set (website technical features, ac- } \\
\text { cess to the website, and social media usage) and the de- } \\
\text { pendent variable set (website usage statistics), and this } \\
\text { relationship has been repeatedly found in different } \\
\text { months. Besides, it is seen that different website fea- } \\
\text { tures emerged and the relationship structure between } \\
\text { variables changed in the months examined. }\end{array}$ \\
\hline \multicolumn{2}{|c|}{$\begin{array}{l}\text { Anahtar Kelimeler: E-Ticaret, E-Ticaret Pazaryerleri, } \\
\text { Web Sitesi Özellikleri, Covid-19 Pandemisi }\end{array}$} & $\begin{array}{l}\text { Keywords: E-Commerce, E-Commerce Marketplaces, } \\
\text { Web Site Features, Covid-19 Pandemic }\end{array}$ \\
\hline \multicolumn{2}{|c|}{ JEL Kodları: M30, M15, L81 } & JEL Codes: M30, M15, L81 \\
\hline \multicolumn{3}{|l|}{$\begin{array}{c}\text { Araştırma ve } \\
\text { Yayın Etiği } \\
\text { Beyanı }\end{array}$} \\
\hline $\begin{array}{c}\text { Yazarların } \\
\text { Makaleye Olan } \\
\text { Katkıları }\end{array}$ & \multicolumn{2}{|c|}{ Çalışmanın tamamı iki yazar ile birlikte oluşturulmuştur. Çalışma genelinde yazarların katkısı eşit düzeydedir. } \\
\hline Çıkar Beyanı & \multicolumn{2}{|c|}{ Yazarlar açısından ya da üçüncü taraflar açısından çalışmadan kaynaklı çıkar çatışması bulunmamaktadır. } \\
\hline
\end{tabular}

\footnotetext{
${ }^{1}$ Çalışmada kullanılan verilere ait tanımlayıcı analiz sonuçları 04.12.2020 tarihinde 5. Marmara Sosyal Bilimler Kongresi'nde bildiri olarak sunulmuştur. Bu çalışmada sunulan bulgular bildiriden tamamen farklıdır.

2 Doç. Dr., Bursa Teknik Üniversitesi İnsan ve Toplum Bilimleri Fakültesi, İşletme Bölümü. ramazan.nacar@btu.edu.tr

${ }^{3}$ Arş. Gör., Şırnak Üniversitesi IïBF, İşletme Bölümü. kadirozdemir@sirnak.edu.tr
} 


\section{Giriş}

Teknolojik gelişmelerle birlikte dünya genelinde internet ve e-ticaret kullanımı gün geçtikçe artmaktadır (Thompson vd., 2019: 239). Tüketicilere ve işletmelere daha kolay, daha hızlı, daha kaliteli ve daha az maliyetli işlem yapabilme fırsatı veren e-ticaret (Gangeshwer, 2013:187; Niranjanamurthy vd., 2013: 2362-2364) tarafların fiziksel temastan kaçınarak elektronik ortamda her türlü işlemi yapabilmesini sağlamaktadır (Gupta, 2014: 1). E-ticaretle birlikte işletmeler için önem arz eden birçok faaliyet ve kavram değişmiştir (Barkatullah ve Djumadi, 2018: 94). Bu bağlamda dünya genelinde hızla yayılan e-ticaret, işletmelerin faaliyetlerini sürdürebilmek için kullanmak zorunda oldukları bir uygulamaya dönüşmüştür (Kotler, 2017: 187).

Özellikle Covid-19 pandemi döneminde ticari ve sosyal açıdan değişimlerin olması (Duygun ve Şen, 2020: 50) birçok faaliyetin internet ortamına taşınmasına ve fiziksel temastan kaçınan müşterilerin daha fazla e-ticaret üzerinden alışveriş yapmasına sebep olmuştur (Tran, 2020: 12). Bu dönemde yapılan birçok araştırma müşterilerin yarıdan fazlasının fiziksel mağazadan değil, e-ticaret üzerinden alışveriş yapmak istediği (Bhatti vd., 2020: 1450) ve bu bağlamda e-ticaret web sitelerinin trafiğinin, ziyaretçi sayılarının ve satışlarının önemli derecede arttığı sonucuna ulaşmıştır (Statista, 2020).

Müşterileri ve satıcıları elektronik ortamda buluşturan ve gerçekleştirilen işlemlere aracılık eden e-ticaret pazaryeri web siteleri (İyiler, 2009: 4) bu gelişmeler ve değişimlerde önemli bir rol oynamıştır. Çünkü e-ticaret pazaryerleri aracılığıyla işletmeler hiçbir tanıtım ve altyapı maliyetine katlanmadan kolayca e-ticarete başlayabilmekte ve geniş müşteri kitlesine ulaşabilmektedir. Bu durum hem müşterilerin hem de satıcıların e-ticaret pazaryeri web sitelerini daha fazla kullanmasını sağlamaktadır (İsayev ve Nart, 2019: 20).

E-ticaret pazaryeri web sitelerinin kullanımının artması bu web sitelerinin domain yaşı, sayfa hızı, sayfa açılma süresi ve sayfa boyutu gibi web sitesi teknik özelliklerini daha önemli bir hale getirmiştir. Çünkü daha kaliteli ve daha fazla tercih edilen bir web sitesine sahip olmak isteyen işletmeler için web sitesi teknik özellikleri önem arz etmektedir (Wagner vd., 2014: 270). Bununla birlikte web sitesi teknik özelliklerinin doğrudan etkilediği web sitesi bilinirliği, web sitesi etkileşimi ve web sitesi kullanım istatistikleri de müşterilerin web sitelerini nasıl algıladıklarını anlamak açısından önemlidir. Çünkü müşteriler genellikle bildikleri web sitelerini daha fazla ziyaret etmektedir (Park ve Lee, 2009: 62). Bu durum ziyaretçi sayıları, web sitesinde ortalama geçirilen süre, ziyaret başına görüntülenen sayfa sayısı, siteden hemen ayrılma oranı ve hangi ülkelerdeki müşterilerin web sitesini daha fazla ziyaret ettiği gibi kullanım istatistiklerini etkilemektedir (Similarweb, 2020a). Ayrıca e-ticaret pazaryeri web siteleri satışlarını artırmak için müşterileri web sitesine çekmek ve müşteri trafiği oluşturmak zorundadır. Bu bağlamda web sitesine giriş kaynakları ve web sitesi için yapılan aramalar önem arz etmektedir. Müşteriler eticaret web sitelerine reklamlar, sosyal medya platformları, e-posta ve arama motorları aracilığıyla veya direkt olarak giriş yapabilmektedir (Similarweb, 2020a; Plaza, 2011: 477-480; Carmona vd., 2012: 11246; Pakkala vd., 2012: 506).

Bu çerçevede çalışma, web sitelerinin domain yaşı, sayfa hızı, sayfa açılma süresi ve sayfa boyutu gibi teknik özellikleri, ziyaretçi sayıları, web sitesinde ortalama geçirilen süre, ziyaret başına görüntülenen sayfa sayısı, siteden hemen ayrılma oranı ve web sitesini en çok ziyaret eden ülkelerin ortalaması gibi web sitesi kullanım istatistikleri ve web sitesine direkt giriş, reklamlar, sosyal medya platformları, e-posta ve arama motorları gibi web sitesi aramaları ve giriş kaynaklarının birbirleri ile olan ilişkisine ve birbirleri üzerindeki etkisine odaklanmıştır. 


\section{Kavramsal Çerçeve}

\subsection{E-Ticaret}

Günümüzde, internet ve internet teknolojilerinin gelişmesiyle dünya genelinde internet kullanıcı sayısı ve internet üzerinden alışveriş yapma oranı artmaktadır (Thompson vd., 2019: 239). Bu gelişmeler nedeniyle geleneksel ticaret önemli bir dönüşüm yaşamıştır. E-ticaret olarak adlandırılan bu yeni iş modeli (Almousa, 2013: 65; Barkatullah ve Djumadi, 2018: 94), tarafların fiziksel temas kurmak yerine elektronik ortamda gerçekleştirdiği her türlü ticari faaliyeti ifade etmektedir (Gupta, 2014: 1). E-ticaretle birlikte işletmeler için hayati önem taşıyan müşteri ilişkileri, ödeme şekli, lojistik ve rekabet gibi birçok kavram değişikliğe uğramıştır (Barkatullah ve Djumadi, 2018: 94). Geleneksel ticareti değiştiren en önemli etmen ise küreselleşmedir. Küreselleşme, rekabet avantajı elde etmek isteyen işletmeleri pazarlama uygulamalarını ve stratejilerini değiştirmek zorunda bırakmıştır (Marangoz, 2014: 39). Ayrıca e-ticaret, müşterilerin daha ucuz ve daha kaliteli ürünlere istedikleri yerden ve istedikleri zaman ulaşmasına imkân sağlamaktadır (Barkatullah ve Djumadi, 2018: 94).

E-ticareti kullanan işletmelerin büyüme hızlarının arttığını ve rakiplerine karşı avantaj elde ettiği gözlemlenmiştir (Almousa, 2013: 65). Ayrıca e-ticaret işletmeler, üreticiler, dağıtıcılar ve müşteriler arasındaki ilişkiyi geliştirmektedir (Chosssin ve Ghaffari, 2017: 67). Literatürde internet pazarlaması (Heinen, 1996: 7) olarak da adlandırılan e-ticaret daha az maliyetli, daha hızlı, daha verimli ve daha kaliteli bir pazarlama yöntemi olarak dünya genelinde hızla yayılmaktadır (Niranjanamurthy vd., 2013: 2362-2364). Bu bağlamda, müşterilerin e-ticaret kullanmasındaki artış birçok işletmenin geleneksel ticaretle birlikte e-ticareti kullanmasını da zorunlu bir hale getirmiştir (Kotler, 2017: 187).

Covid-19 pandemisiyle birlikte dünya genelinde bireysel, sosyal ve ticari açıdan birçok değişiklik meydana gelmiştir (Duygun ve Şen, 2020: 50). Müşteriler fiziksel temastan kaçındığından birçok faaliyet internet ortamına taşınmıştır ve hem işletmeler hem de tüketiciler e-ticareti daha fazla kullanmaya başlamıştır (Tran, 2020: 1-2). Yapılan araştırmalar bu dönemde müşterilerin \%52'sinin fiziksel mağazalardan alışveriş yapmak istemediği ve e-ticareti tercih ettiğini göstermektedir (Bhatti vd., 2020: 1450). Bu bağlamda, Statista 2020 yılında yapmış olduğu araştırmada moda, elektronik, gıda, sağlık ve güzellik ürünleri, ev ve bahçe ürünleri, bebek ve çocuk ürünleri, hediye ve çiçek, spor ürünleri ve evcil hayvan ürünlerini kapsayan sektörlere ait $A B D$, Ingiltere, Avustralya, Almanya, Fransa, İspanya, İtalya, Rusya, Brezilya ve Japonya'daki en çok ziyaret edilen 2000 'den fazla e-ticaret web sitesini incelemiştir. Bulgulara göre bu sitelerin aylık ortalama ziyaretçi sayıları Ocak 2020'de 16,07 milyar, Şubat 2020'de 17,64 milyar, Mart 2020 'de 18,35 milyar, Nisan 2020'de 18,55 milyar, Mayıs 2020'de 21,28 milyar ve Haziran 2020 'de 21,96 milyardır. Buna göre Covid-19 pandemisinin e-ticaret web sitelerinin trafiğini önemli derecede etkilediği ve ziyaretçi sayılarının artmasına sebep olduğu görülmektedir (Statista, 2020).

Literatürde Covid-19 pandemi döneminde e-ticaret ile ilgili birçok çalışma yapıldığı görülmektedir. Fakat çalışmaların genellikle pandeminin tüketici davranışları üzerindeki etkisine odaklandığı tespit edilmiştir. Örneğin, Duygun ve Şen yapmış oldukları çalışmada Covid-19 pandemisinde tüketicilerin satın alma davranışlarını Maslow ihtiyaçlar hiyerarşisi teorisine göre analiz etmiştir (Duygun ve Şen, 2020). Chaudhary yapmış olduğu çalışmada pandemi döneminde tüketici davranışlarının nasıl değiştiğini ve e-ticaret kullanımının nasıl arttığını incelemiştir (Chaudhary, 2020). Hasanat ve diğerleri (2020) yapmış oldukları çalışmada Covid-19 pande- 
misinin ve tüketici davranışlarının Malezya'daki e-iş hayatını nasıl etkilediğini incelemiştir. Pantelimon ve diğerleri (2020) yapmış oldukları çalışmada e-ticaretin Almanya ve Romanya'nın GSYiH'Sı üzerindeki etkisini karşılaştırmalı bir şekilde analiz etmiş ve Covid-19 pandemisinin dünya genelindeki e-ticaret faaliyetlerini nasıl etkilediğini incelemiştir. Yuan ve diğerleri (2020) ise yapmış oldukları çalışmada Covid-19 pandemisinin Çin'deki e-ticaret pazarı ve tüketici davranışları üzerindeki etkisini incelemiştir. Yapılan çalışmalar neticesinde genel itibariyle Covid-19 pandemi döneminde tüketicilerin tüketim alışkanlıklarının değiştiği ve e-ticaret kullanımının arttığı görülmektedir. Bu durum da e-ticaret pazaryeri web sitelerini hem tüketiciler hem de işletmeler için daha önemli bir hale getirmiştir (Statista, 2020).

\subsection{E-Ticaret Pazaryerleri}

E-ticareti kullanan işletmeler öncelikle gerekli alt yapıyı oluşturup kendi web siteleri üzerinden satış yapabilmektedir. Web sitesi aracılığıyla işletmeler müşterilerle doğrudan iletişim kurmakta ve tüm potansiyel problemler ile kendileri ilgilenmektedir (Bodkin ve Perry, 2004: 19). Bunun dışında alternatif olarak işletmeler Facebook, Instagram vb. gibi sosyal medya platformları üzerinden ürünlerini satabilmektedir. Özellikle son yıllarda sosyal medya kullanımının artmasıyla birlikte sosyal medya pazarlaması müşteriye kolay ulaşmak ve marka değerini artırmak amacıyla daha çok tercih edilmektedir (Chen ve Lin, 2019: 23). Son olarak işletmeler Amazon, Aliexpress vb. gibi e-ticaret pazaryerlerinde mağaza açıp ürünlerini müşterilere sunabilmektedir. Özellikle e-ticarete yeni başlamış işletmeler için e-ticaret pazaryerleri müşterilere ulaşma, güvenilirlik ve bilinirlik kazanma açısından önem arz etmektedir (Chow, 2020: 1-5).

E-ticaret pazaryerleri işletmeler için yeni pazarlara girmenin ve hedef müşterilere ulaşmanın en kolay ve hızlı yolu olarak bilinmektedir. İşletmeler, pazaryerleri aracılığıyla herhangi bir alt yapı ve tanıtım maliyetine katlanmadan e-ticarete başlayabilmektedir (İsayev ve Nart, 2019: 20). E-ticaret pazaryerleri işletmelerin yaşadıkları pazarlama problemlerine sunulan en önemli çözümlerden biridir. E-ticaret pazaryerleri, satıcı ile alıcıyı internet ortamında bir araya getiren ve satın alma işlemine aracılık eden web siteleridir. (Özbek ve Esmer, 2019: 71-72; Kuşat, 2016: 692-694; İyiler, 2009: 4). Bu pazaryerlerinde satıcı ve alıcının fiziki olarak bir araya gelmesine, birbirlerini tanımasına gerek yoktur. İnternet ortamında kurulan iletişimle birlikte tüm satış işlemleri çevrimiçi olarak yapılabilmektedir (Çelik, 2019: 31-32).

Özellikle e-ticarete yeni başlayan işletmeler e-ticaret pazaryerlerini kullanarak birçok avantaj elde edebilmektedir. Bu pazaryerleri, işletmeleri daha geniş bir müşteri kitlesine ulaştırmaktadır. Ek olarak e-ticaret pazaryerleri, işletmelerin kendi web sitelerini ve alt yapılarını kurmalarına kıyasla daha az maliyetlidir. Pazaryerlerinde mağaza açan işletmeler teknik sorunlarla ilgilenmek zorunda kalmadan sadece satışa odaklanabilmektedir. Ayrıca pazaryerlerinin sunduğu gözlemlenebilir rekabet ortamı işletmelerin rakiplerini takip etmesi, analiz etmesi ve kendi verileriyle karşılaştırması açısından önem arz etmektedir. (Oypan, 2018; İsayev ve Nart, 2019: 20). E-ticaret pazaryerlerinde müşteriler, yüzlerce tedarikçi ve satıcıyı tek bir işlem ile karşılaştırıp kendilerine kalite ve fiyat olarak en uygun olanı seçebilmektedir. Dinamik bir yapıya sahip olan e-ticaret pazaryerleri satıcılara ürünlerini hızlı bir şekilde müşteriyle buluşturma imkânı sunduğu için satıcıların stok ve depolama problemini büyük oranda çözmektedir (Çelik, 2019: 3234).

Bu avantajların yanı sıra e-ticaret pazaryerlerinin dezavantajları da bulunmaktadır. E-ticaret pazaryerlerinde mağaza açmak isteyen işletmeler mağaza açma bedeli ve satışlardan verilecek komisyon bedeline katlanmak zorundadır. Pazaryerlerinde benzer ürünleri satan birçok işletme 
olduğu için rekabette öne çıkmak çok zordur. Reklamlar ve sunulan iyi hizmetten dolayı müşterilerden alınacak olumlu yorumlar ile ön plana çıkmak ve rekabetten sıyrılmak mümkündür. Pazaryerlerinde mağaza açan işletmelerin her pazaryerinin kendine özgü olan, müşteri memnuniyeti ve güvenini amaçlayan kurallarına uyması gerekmektedir. Belirlenen kurallara uyulmaması durumunda işletmelere mağazanın kapanmasına kadar uzanan ciddi yaptırımlar uygulanmaktadır (Oypan, 2018; İsayev ve Nart, 2019: 20; Chow, 2020: 1-5). Ayrıca e-ticaret pazaryerlerinde tüketicilerin fiziksel olarak satıcıyı ve ürünleri görememesinden kaynaklanan belirsizlik ve risk tüketicilerin satın alma kararını etkileyen önemli faktörlerdendir (Chong vd., 2018: 623).

\subsection{Web Sitesi Teknik Özellikleri}

Web sitesi teknik özellikleri kaliteyi ve buna bağlı olarak web sitesi kullanılabilirliğini etkileyen en önemli faktörler arasındadır. Rakiplere kıyasla müşteri algısında daha kaliteli ve daha çok tercih edilen web sitesine sahip olmak isteyen işletmelerin web sitesi teknik özelliklerine daha fazla dikkat etmesi gerekmektedir. Web sitesinin tipolojisi, boyutu, sayfaların açılma hızı, yazı tipi ve kullanılan renkler gibi teknik özellikler kaliteli bir web sitesinde önde gelen unsurlar arasındadır (Wagner vd., 2014: 270).

Bu bağlamda literatür kapsamında bu çalışmada kullanılan ve web site kalitesini etkileyen teknik özellikler Tablo 1'de gösterilmiştir.

Tablo 1: Web Sitesi Teknik Özellikleri

\begin{tabular}{lcccc}
\hline \multirow{2}{*}{ Yazar } & Yıl & \multicolumn{3}{c}{ Web Sitesi Teknik Özellikleri } \\
\cline { 3 - 5 } & & Web sitesi sayfa hızı & Sayfa açılma süresi & Sayfa boyutu \\
\hline Zhang vd. & 1999 & & + \\
Albuquerque ve Belchior & 2002 & + & \\
Cao vd. & 2005 & + & + \\
Choudhury ve Choudhury & 2010 & + & + & + \\
Rababah ve Masoud & 2010 & + & + & + \\
Egger vd. & 2012 & & + \\
Mansah & 2013 & + & + \\
Kiyea ve Yusuf & 2014 & & + \\
Rakhmawati vd. & 2017 & + & + \\
Elisa & 2017 & + & + \\
Bilal vd. & 2019 & + & + \\
\hline
\end{tabular}

Not: Yazarlar tarafından oluşturulmuştur.

Tablo 1'e göre, Albuquerque ve Belchior (2002) yapmış oldukları çalışmada kaliteli e-ticaret web sitelerinin oluşturulması için e-ticaret web siteleri kalite faktörlerini belirlemiştir. Web sitesi sayfa hızı da belirlenen kalite faktörleri arasında yer almaktadır. Rababah ve Masoud (2010) ise yapmış oldukları çalışmada başarılı ve kaliteli e-ticaret web sitelerinde olması gereken faktörleri belirlemiştir ve web sitesi hızı bu faktörler arasında yer almaktadır. Mansah (2013) yapmış olduğu çalışmada etkili bir web sitesi performansı için gerekli olan web sitesi sayfa hızı ve sayfa açılma süresi faktörlerini incelemiştir. Bir diğer çalışmada ise web sitesi ulaşılabilirliği ve kullanılabilirliğini doğrudan etkileyen web sitesi sayfa hızı, sayfa açılma süresi ve sayfa boyutu faktörleri incelenmiştir (Bilal vd., 2019).

Web sitesi teknik özelliklerindeki önemli unsurlar web sitesi hızı (Cao vd., 2005: 645-648) sayfaların açılma süresi (Mansah, 2013: 32-33) ve sayfa boyutudur (Kiyea ve Yusuf, 2014: 8). Resim görüntülemelerinde, sayfa geçişlerinde veya ürün siparişlerinde müşteriler belli bir süre 
beklemektedir. Web sitesi kalite algısıyla doğrudan ilişkili olan bekleme süresinin olabildiğince az olması gerekmektedir. Bekleme süresi ne kadar uzun olursa müşteri memnuniyeti o kadar azalmaktadır. Sonuç olarak müşterilerin algıladıkları web sitesi kalitesi üzerinde bekleme süreleri ve web sitesi hızı çok büyük etkiye sahiptir (Egger vd., 2012: 86-87).

Sayfa boyutu, web sitesi hızı ve müşterilerin bekleme süreleriyle doğrudan ilgili olduğu için web sitesi kalitesi açısından önem arz etmektedir. Sayfa boyutu, sitedeki görsellerin kalitesine ve web sitesindeki içerik fazlalığına göre artış göstermektedir. Küçük ve hızlı açılan bir web sitesinin sayfa boyutu yaklaşık olarak 12 KB'tır. Ortalama hızdaki bir web sitesinin sayfa boyutu genellikle $2 \mathrm{MB}^{\prime} ı$ altındadır. Web sitesi sayfa hızının yavaş ve sayfa açılma süresinin fazla olması sayfa boyutunun fazla olmasına bağlıdır. Sayfa boyutunu artıran en önemli faktörler ise gömülü videolar, resimler, sesler ve diğer medya unsurlarıdır. Yavaş açılan web sitelerinin sayfa boyutu ise genellikle $2 \mathrm{MB}^{\prime} ı$ üzerindedir. Sayfa boyutu fazla olan ve yavaş açılan siteleri müşteriler genellikle hemen terk etmektedir. Sayfa boyutuna bağlı olan web sitesi hızı müşterilere iyi bir deneyim yaşatmakta ve müşteri memnuniyetini artırmaktadır. Bu bağlamda işletmeler, kullanıcıları oyalamayan hızlı web sitelerine sahip olmak için sayfa boyutlarını olması gereken düzeye getirmek zorundadır (Elisa, 2017: 45; Kiyea ve Yusuf, 2014: 7-10; Bilal vd., 2019: 317-319).

Google ve Deloitte tarafından yapılan araştırmada 37 markanın web sitesi 30 gün boyunca incelenmiştir. Araştırma sonuçlarına göre web sitesinin hızı arttıkça daha fazla müşteri ödeme aşamasına ulaşmakta ve alışveriş yapmaktadır. Ayrıca müşteriler daha hızlı olan sitelerde daha fazla vakit geçirmekte ve daha fazla alışveriş yapmaktadır. Bu nedenle müşteri sayısını artırmak, müşterilere iyi bir alışveriş deneyimi sunmak ve müşteri memnuniyetini artırmak isteyen işletmelerin web sitesi hızlarını sürekli olarak takip etmesi ve açılma süresini optimum düzeyde tutması gerekmektedir (Boulte, 2020). Bununla birlikte, Avrupa, Asya ve Orta Doğu'daki 15 ülkeden 20.000'den fazla tüketicinin katıldığı bir araştırmada 10 tüketiciden yedisinin web sitelerindeki alışveriş sürecinin zor ve sinir bozucu olmasından dolayı alışverişlerini tamamlamadığı ve web siteyi hemen terk ettiği sonucuna ulaşılmıştır (Stratta ve Voxlin, 2020).

Ayrıca domain yaşı web site teknik özelliklerinde dikkat edilmesi gereken önemli unsurlardan biridir. Domain yaşının arama motoru optimizasyonuna etkisi büyüktür. Arama motorundaki sıralamalarda domain yaşı önemli rol oynamaktadır. Bunun sebebi, Google ve Yandex gibi büyük arama motorları domain yaşı büyük olan eski siteleri daha güvenilir olarak algılamakta ve o siteleri aramalarda üst sıralara taşımaktadır. Yapılan araştırmalara göre domain yaşı en az 3 olmalıdır ve 3 yılın altındaki domainler arama motorları tarafından önemsenmemektedir (Günay, 2012).

\subsection{Web Sitesi Bilinirliği, Etkileşimi ve Kullanım İstatistikleri}

Web sitesi bilinirliği ve etkileşimi insanların web sitesini nasıl algıladıklarıyla ilgilidir. Web sitesi bilinirliği olumlu, olumsuz veya tarafsız olabilmektedir. Müşteriler, e-ticaret web sitesi hakkındaki algılarını web sitesi ile etkileşim kurarken kullanmaktadır ve bu algılar onların davranışlarını önemli derecede etkilemektedir. Bilinirlik tek başına bir anlam ifade etmemektedir ve bilinirliği belirleyen birçok faktör bulunmaktadır. Web sitesindeki hizmet kalitesi, bilgi kalitesi, siparişlerdeki hızı teslimat, akılda kalıcı domain ismi ve yüksek kaliteli içerik gibi faktörler bilinirliği belirlemektedir. Web sitesi bilinirliğini ve etkileşim oranını artırmanın birçok yolu bulunmaktadır (Toms ve Taves, 2004: 293-294). Özellikle kulaktan kulağa pazarlama yoluyla işletmeler web sitelerinin bilinirliğini artırmaktadır. Müşteriler web sitesinden kaliteli bir ürün aldığında, uygun fiyatlı bir ürün aldığında, ürün satın alırken kendisiyle kurulan iletişimden memnun 
kaldığında veya web sitesi içeriğini ve tasarımını beğendiğinde çevresine web sitesiyle ilgili tavsiyelerde bulunmaktadır. Böylece web sitesinin bilinirliği ve etkileşimi artmaktadır (Toms ve Taves, 2004: 293-294; Park ve Lee, 2009: 61-62).

Bilinirliği yüksek olan web siteleri diğer web sitelerine oranla müşteriler tarafından daha çok tercih edilmektedir. Bu durum web sitelerinin toplam ziyaretçi sayısını da artırmaktadır (Park ve Lee, 2009: 62). E-ticarette müşterilerin bir web sitesinden alışveriş yapmalarının en önemli nedenlerinden biri web sitesi (marka) bilinirliğidir. Web sitesi bilinirliği, markanın ve ürünlerin müşterinin aklında kalmasıdır. Özellikle sadece internet üzerinden satış yapan işletmeler, müşterilerin aklında yer etmedikçe ve onların güvenini kazanmadıkça rekabetçi ortamda tutunamamaktadır. Ayrıca web sitesi bilinirliği yeni müşterilere ve pazarlara ulaşmanın anahtarıdır (Oypan, 2020).

Web sitesi bilinirliği ziyaretçi sayıları, web sitesinde geçirilen ortalama süre, ziyaret başına görüntülenen sayfa sayısı, siteden hemen ayrılma oranı ve hangi ülkelerin web sitesini ziyaret ettiği gibi kullanıcı istatistiklerini önemli derecede etkilemektedir (Similarweb, 2020a). Çünkü müşteriler bildikleri web sitelerini daha sık ziyaret etmekte ve daha fazla alışveriş yapmaktadır (Park ve Lee, 2009: 62). Bu bağlamda Tablo 2'de web sitesi kullanım istatistiklerinin literatürde yer alan bazı çalışmalar özetlenmiştir.

Tablo 2: Web Sitesi Kullanım istatistikleri

\begin{tabular}{|c|c|c|c|c|c|c|}
\hline \multirow[b]{2}{*}{ Yazar } & \multirow[b]{2}{*}{ Yil } & \multicolumn{5}{|c|}{ Web Sitesi Kullanım İstatistikleri } \\
\hline & & $\begin{array}{c}\text { Ziyaretçi sa- } \\
\text { yısı }\end{array}$ & $\begin{array}{l}\text { Geçirilen or- } \\
\text { talama süre }\end{array}$ & $\begin{array}{c}\text { Ziyaret başına gö- } \\
\text { rüntülenen sayfa } \\
\text { sayısı }\end{array}$ & $\begin{array}{l}\text { Siteden hemen } \\
\text { ayrılma oranı }\end{array}$ & $\begin{array}{l}\text { En çok ziyaret } \\
\text { eden ülkeler }\end{array}$ \\
\hline Nicholas vd. & 2002 & & & + & & \\
\hline Danaher vd. & 2006 & & + & & & \\
\hline Hasan vd. & 2009 & & + & + & + & \\
\hline Omidvar vd & 2011 & & & + & & \\
\hline Pakkala vd. & 2012 & + & + & + & + & \\
\hline Carmona vd & 2012 & + & + & + & & \\
\hline Fagan & 2014 & + & & + & + & \\
\hline Dias ve Ferreira & 2017 & & & & + & \\
\hline Sulova & 2019 & + & + & + & + & + \\
\hline Poulos vd. & 2020 & & & & + & \\
\hline
\end{tabular}

Not: Yazarlar tarafından oluşturulmuştur

Literatürde web sitelerinin kullanım istatistikleri ile ilgili birçok çalışma bulunmaktadır. Örneğin, Hasan ve diğerleri (2009) e-ticaret web sitelerinin kullanılabilirliğini ve kullanım istatistiklerini Google Analitik kullanarak; Pakkala ve diğerleri (2012) gıda satan e-ticaret web sitelerinin kullanım ve ziyaretçi istatistiklerini Google Analitik kullanarak; Carmona ve diğerleri (2012) zeytinyağı satan bir işletmeye ait web sitesinin kullanım istatistiklerini Google Analitik kullanarak incelemiştir. Sulova (2019) ise e-ticaret web sitelerinin nasıl değerlendirilmesi gerektiğini ve bu değerlendirmede temel performans göstergesi olarak kullanım istatistiklerinin nasıl kullanılması gerektiğini ortaya koymuştur. Bu bağlamda, Tablo 2'de yer alan literatürdeki çalışmalara göre;

Ziyaretçi Sayısı: Web sitesini ziyaret eden tahmini müşteri sayısını ifade etmektedir (Pakkala vd., 2012: 506). 
- Web Sitesinde Geçirilen Ortalama Süre: Müşterilerin web sitesinde geçirdiği ortalama süreyi ifade etmektedir (Pakkala vd., 2012: 506; Carmona vd., 2012: 11246).

Ziyaret Başına Görüntülenen Sayfa Sayısı: Web sitesinde ziyaret başına görüntülenen toplam sayfa sayısını ifade etmektedir ve web sitesinin ne kadar kullanıldığının genel bir ölçüsüdür (Pakkala vd., 2012: 506; Carmona vd., 2012: 11246).

- $\quad$ Siteden Hemen Ayrılma Oranı: Web siteye girip tek bir sayfayı ziyaret eden ve hemen web siteden ayrılan müşterilerin oranını ifade etmektedir (Dias ve Ferreira, 2017: 298; Pakkala vd., 2012: 506). Web sitesinden hemen ayrılma oranını bilmek önem arz etmektedir. Çünkü web sitesinin ziyaretçilerinin hepsi müşteri değildir ve web sitesini hemen terk edebilmektedir. Web sitesinden hemen ayrılma oranı ne kadar az ise e-ticaret web sitesi o kadar başarılıdır (Sulova, 2019: 28).

- $\quad$ En Çok Ziyaret Eden Ülkeler: Web sitesine yapılan ziyaretlerin hangi ülkelerden yapıldığı hakkında bilgi vermektedir. Bu bilgi web sitelerine potansiyel müşterilerinin ulusal değerlerine, kültürlerine ve geleneklerine uygun ürünler sunmasını sağlayabilmektedir (Sulova, 2019: 28).

Ziyaretçi sayısı, geçirilen ortalama süre, ziyaret başına görüntülenen sayfa sayısı, siteden hemen ayrılma oranı ve web sitesini en çok ziyaret eden ülkeler gibi web site kullanım istatistikleri e-ticaret web sitelerinin güçlü ve zayıf yönlerinin belirlenmesinde önemli rol oynamaktadır (Sulova, 2019: 28). Web sitesi kullanım istatistikleri aynı zamanda temel performans göstergeleridir. Web sitesi kullanım istatistikleri ile web sitesinin performansı ve başarısı hakkında bilgi edinilebilmektedir (Fagan, 2014: 26-28).

\subsection{Web Sitesine Giriş Kaynakları ve Web Sitesi için Yapılan Aramalar}

Internet kullanımının artmasıyla birlikte işletmeler, ürün ve marka tanıtımlarını internet üzerinden yapmaya başlamıştır. Özellikle e-ticaret web sitelerinde müşterilerin satın alma davranışı direkt olarak web sitelerinde verilen bilgiler doğrultusunda şekillenmektedir (Chen, 2013: 30). Bu bağlamda e-ticareti kullanan işletmeler satış yapmak için web sitelerinde müşteri trafiği oluşturmak ve müşterileri çekmek zorundadır. Müşteriler, e-ticaret web sitelerine direkt olarak, farklı sitelerdeki reklamlar ve referanslar aracılığıyla, arama motorlarında arama yaparak, sosyal medya platformlarına verilen reklamlarla ve e-postayla giriş yapabilmektedir (Similarweb, 2020a; Plaza, 2011: 477-480; Carmona vd., 2012: 11246; Pakkala vd., 2012: 506).

E-ticaret web sitelerinde trafik oluşturmak için dikkat edilmesi gereken en önemli hususlar hedef müşterileri tanımak ve müşteriler için neyin önemli olduğunu bilmektir. İşletmeler web sitelerinde kaliteli içerik, doğru arama motoru optimizasyonu, sosyal medyanın etkin kullanımı, e-posta listeleri ve reklamların etkin kullanılmasıyla istedikleri düzeyde müşteri trafiği oluşturabilmektedir (Güler, 2019). Web sitesine giriş kaynakları direkt, arama, referans, sosyal medya platformları, e-posta ve reklam olarak sınıflandırılmıştır (Similarweb, 2020a; Carmona vd., 2012: 11246). Bu bağlamda;

Direkt: Web sitesi adresinin doğrudan tarayıcıya yazılarak web siteye giriş yapılmasını ifade etmektedir (Pakkala vd., 2012:506).

- Arama: Arama motorlarında web sitesini aratarak giriş yapılmasını ifade etmektedir (Pakkala vd., 2012:506).

- Referans: Başka bir web sitesindeki bağlantıya tıklanarak web sitesine giriş yapılmasını ifade etmektedir (Pakkala vd., 2012:506). 
- Sosyal Medya Platformları: Facebook, Twitter, Instagram, Whatsapp ve Youtube gibi sosyal medya platformları üzerinden web sitesine giriş yapılmasıdır (Carmona vd., 2012: 11246).

- $\quad$ E-posta: Web sitesine e-posta üzerinden gerçekleştirilen girişleri ifade etmektedir (Carmona vd., 2012: 11246).

Müşterilerin e-ticaret web sitesine direkt olarak girmesinin yanı sıra kullandıkları en önemli giriş kaynakları sosyal medya reklamları ve işletmelerin yapmış olduğu arama motoru optimizasyonudur (Similarweb, 2020a). Sosyal medya kullanımının artmasına paralel olarak işletmeler Facebook, Instagram, Youtube, Whatsapp ve Twitter gibi sosyal medya platformları aracılığıyla markalarını, ürünlerini ve web sitelerini müşterilere tanıtmaktadır (Dhar ve Jha, 2014: 791-792). Bunun dışında internet trafiğinin \%93'ü arama motorları tarafından yönetilmektedir. Arama motorları müşterilerin doğru web sitelerine yönlendirilmesinde çok önemli bir rol oynamaktadır. Arama motoru optimizasyonu, yapılan arama sonucunda web sitelerinin rakiplerinden daha önde görülmesini sağlamaktadır. Bu durum rekabet için çok önemlidir ve birçok işletme doğru arama motoru optimizasyonu için ciddi yatırımlar yapmaktadır (Egri ve Bayrak, 2014: 335-336).

Web sitesi için yapılan aramalar ayrıca organik (doğal) ve satın alınmış (sponsorlu) olarak ikiye ayrılmaktadır. E-ticaret web siteleri müşterilerin arama motorunda arama yaparken kullandığı bazı anahtar kelimeleri satın almaktadır. Böylece müşteriler o kelimeyi arattığında karşısına ilk o kelimeyi satın alan web sitesi çıkmaktadır. Bu durum satın alınmış aramaları ifade etmektedir (Similarweb, 2020a; Blake vd., 2015: 156-158; Rutz vd., 2011: 646). Örneğin Trendyol twitch, PS5, steam ve trendyol gibi kelimeleri satın almıştır (Similarweb, 2020a). Organik aramalar ise herhangi bir satın alma işlemi olmaksızın müşterilerin arattığı kelimeler ile direkt olarak web sitesine giriş yapmasını ifade etmektedir (Similarweb, 2020a; Rutz vd., 2011: 646647).

\section{Araştırmanın Amacı ve Yöntemi}

Araştırmanın amacı Covid-19 pandemi döneminde (Şubat-Mayıs-Ekim 2020) e-ticaret pazaryeri web sitelerine ait web sitesi teknik özellikleri, web sitesine giriş kaynakları ve web sitesi için yapılan aramalar ile web sitesi kullanım istatistikleri arasındaki ilişkiyi araştırmaktır. Araştırmanın verileri Covid-19 pandemisinin farklı dönemlerini temsilen Şubat-Mayıs-Ekim 2020 aylarında Similarweb ve Gtmetrix'ten elde edilmiştir. Similarweb'in (Similarweb, 2020b) yayınladığı Türkiye'de en çok ziyaret edilen 100 web sitesi sıralamasından 16 e-ticaret pazaryeri web sitesi araştırmanın örneklemi olarak seçilmiştir. Bu pazaryeri web siteleri Hepsiburada, Gittigidiyor, N11, Trendyol, Morhipo, Çiçeksepeti, Sahibinden, Arabam, Pttavm, Kitapyurdu, Yemeksepeti, Idefix, Amazon, Amazon (tr), eBay ve Aliexpress'tir. Elde edilen veriler anonim olarak analizlere dâhil edilmiş ve raporlanmıştır.

\subsection{Verilerin Elde Edilmesi ve Analizi}

Elde edilen 16 e-ticaret pazaryeri web sitesinin Şubat 2020, Mayıs 2020 ve Ekim 2020 aylarına ait verileri öne sürülen kanonik bir model aracılığıyla test edilmiştir. Verilerin analizi çalışmada birden çok bağımlı ve bağımsız değişken olduğu için kanonik korelasyon yöntemi kullanılarak gerçekleştirilmiştir.

Kanonik korelasyon analizi iki veya daha fazla değişken seti arasındaki ilişkiyi ölçmek için kullanılan çok değişkenli bir analiz yöntemidir. Kanonik korelasyon, değişken setleri arasındaki ilişkileri değişken setlerine ait doğrusal fonksiyonlar arasında bulunan maksimum korelasyonları tespit ederek analiz etmektedir (Ünlükaplan, 2009: 239). Kanonik korelasyon analizi çoklu 
regresyon analizinin özel bir versiyonu olarak bilinmektedir. Çoklu regresyon analizinde bir tane bağımlı, birden fazla da bağımsız değişken bulunmakta olup bunlar arasındaki ilişki araştırılmaktadır. Fakat kanonik korelasyon analizinde birden fazla bağımlı ve bağımsız değişken bulunmaktadır. Kanonik korelasyon analizi en gelişmiş ilişki analizi olarak bilinmektedir ve birden fazla boyutu olan kitleden alınan iki ve daha fazla değişken seti arasındaki ilişkiyi araştırmaktadır (Çemrek, 2012: 202).

Kanonik korelasyon analiz ile birim varyanslı, birbirinden bağımsız ve değişkenler arasındaki korelasyonu maksimize eden kanonik fonksiyonlar (kanonik varyete) elde edilmektedir. Her fonksiyonun bir varyete çifti bulunmaktadır. Bu varyeteler değişken setlerini ifade etmektedir. Değişken setlerinden elde edilecek kanonik fonksiyon (varyete) sayısı değişken sayısı az olan set ile eşittir. Kanonik korelasyondaki temel unsur değişken setleri arasındaki ilişkinin maksimum düzeyde tespit edilmesidir. Bu bağlamda birinci kanonik varyete çifti değişkenler arasındaki maksimum korelasyonu verecek şekilde elde edilirken her yeni varyetede kanonik korelasyon değeri azalmaktadır (Ünlükaplan, 2009: 239). Değişken setlerine ait kanonik denklemler aşağıdaki gibi gösterilmektedir;

$$
\begin{aligned}
& U_{r}=a_{r 1} X_{1}+a_{r 2} X_{2}+a_{r 3} X_{3}+a_{r 4} X_{4}+\ldots+a_{r p} X_{p} \\
& V_{r}=b_{r 1} Y_{1}+b_{r 2} Y_{2}+b_{r 3} Y_{3}+b_{r 4} Y_{4}+\ldots+b_{r q} Y_{q}
\end{aligned}
$$

$r$, değişken setlerindeki en az sayıdaki değişken setine eşittir. Değişken setleri arasındaki ilişkiler $u_{r}$ ve $v_{r}$ arasındaki korelasyonu maksimize edecek şekilde seçilmektedir. Kanonik varyete çiftleri $\left(u_{1}-v_{1}\right),\left(u_{2}-v_{2}\right),\left(u_{3}-v_{3}\right),\left(u_{4}-v_{4}\right) \ldots\left(u_{r}-v_{r}\right)$ şeklinde gösterilmektedir (Ünlükaplan, 2009: 240; Çemrek, 2012: 204).

Araştırma verilerinden web sitesi teknik özellikleri (domain yaşı, sayfa hızı, sayfa açılma süresi, sayfa boyutu), web sitesine giriş kaynakları (doğrudan, arama, referans, sosyal medya, eposta ve reklam) ve referans sosyal medya (YouTube, Facebook, WhatsApp, Twitter, Instagram) değişkenleri kanonik modelde bağımsız değişkenler seti olarak ele alınmıştır. Diğer taraftan, web sitesi kullanım istatistikleri (dünya sıralaması, Türkiye sıralaması, geçirilen ortalama süre, siteden hemen ayrılma oranı, ziyaretçi sayısı, ziyaret başına görüntülenen sayfa sayısı) ise kanonik modelde bağımlı değişkenler seti olarak ele alınmıştır. Aşağıdaki tabloda değişken türleri ve ölçümüyle ilgili bilgiler özetlenmiştir.

\begin{tabular}{|c|c|c|}
\hline Değişken adı & $\begin{array}{l}\text { Değişken } \\
\text { türü }\end{array}$ & Ölçü Birim (Ölçüm açıklaması) \\
\hline Domain yaşı & Bağımsız & Yıl (Web sitesinin oluşturulması sonrası 2020 yılındaki yaşı) \\
\hline Sayfa hızı & Bağımsız & \% - Yüzde (Web sitesi sayfa performansının \% kaç olduğu) \\
\hline Sayfa açılma süresi & Bağımsız & Saniye (Web sitesinin kaç saniyede açıldığı) \\
\hline Sayfa boyutu & Bağımsız & MB (Web sitesinin kaç megabayt büyüklüğ̈̈nde olduğu) \\
\hline Web sitesine giriş kaynakları & Bağımsız & \% - Yüzde (Web site trafiğini oluşturan giriş kaynaklarının dağılımı) \\
\hline Referans sosyal medya & Bağımsız & $\begin{array}{l}\text { \% - Yüzde (Web sitesi trafiğini oluşturan referans sosyal medyaların } \\
\text { dağılımı) }\end{array}$ \\
\hline Dünya sıralaması & Bağımlı & Sayı (Web sitesinin dünyadaki sıralaması) \\
\hline Türkiye sıralaması & Bağımlı & Sayı (Web sitesinin Türkiye'deki sıralaması) \\
\hline Geçirilen ortalama süre & Bağımlı & Dakika (Web sitesinde geçirilen ortalama süre) \\
\hline Siteden hemen ayrılma oranı & Bağımlı & \% - Yüzde (Ziyaretçilerin web sitesinden hemen ayrılma oranı) \\
\hline Ziyaretçi sayısı & Bağımlı & Sayı (Web sitesine gelen toplam ziyaretçi sayısı) \\
\hline $\begin{array}{l}\text { Ziyaret başına görüntülenen } \\
\text { sayfa sayısı }\end{array}$ & Bağımlı & $\begin{array}{l}\text { Sayı (Ziyaretçilerin ziyaret başına web sitesinde görüntüledikleri sayfa } \\
\text { sayısı) }\end{array}$ \\
\hline
\end{tabular}

Tablo 3: Araştırma Verileri ve Ölçümü 
Böylelikle araştırmanın kanonik modeli aşağıdaki şekilde oluşturulmuştur (Ünlükaplan, 2009: 239-240):

$\mathbf{U}=\mathbf{a}_{1}($ Domain yaşı $)+\mathbf{a}_{2}\left(\right.$ Sayfa hızı) $+\mathbf{a}_{3}($ Sayfa açılma süresi $)+\mathbf{a}_{4}($ Sayfa boyutu $)+\mathbf{a}_{5}($ Web sitesine giriş kaynakları) + $\mathbf{a}_{6}$ (Referans sosyal medya)

$\mathbf{V}=\mathbf{b}_{\mathbf{1}}$ (Dünya sıralaması $)+\mathbf{b}_{\mathbf{2}}$ (Türkiye sıralaması $)+\mathbf{b}_{\mathbf{3}}$ (Geçirilen ortalama süre $)+\mathbf{b}_{\mathbf{4}}$ (Siteden hemen ayrılma oranı) + $\mathbf{b}_{5}$ (Ziyaretçi sayısı) + $\mathbf{b}_{6}$ (Ziyaret başına görüntülenen sayfa sayIsI)

$\mathbf{U}=\mathbf{r} \mathbf{V}$

Kanonik modelde temel olarak her bir değişkenin kanonik fonksiyona (varyete) olan katkısı ( $a, b$ : kanonik yükler) hesaplanmaktadır. Daha sonra ise kanonik fonksiyonlar arası ilişki ( $r$ : $k a-$ nonik (setler arası) korelasyon katsayısı) hesaplanmakta ve test edilmektedir (Wilk's $\lambda$ ). Tüm bunların haricinde gerek setler içerisinde gerekse de setler arasında korelasyon katsayıları, her bir set için standardize ve ham kanonik katsayılar, her bir setin gerek set içerisinde gerekse de karşı set içerisindeki kanonik yükleri ve set içinde oluşan varyansı açıklama oranı (fazlalık indeksi) da hesaplanmaktadır (Kalaycı, 2006: 237-254). Dolayısıyla araştırmanın hipotezleri;

$\boldsymbol{H}_{1}$ : Şubat 2020'de bağımlı ve bağımsız değişken setleri arasında ilişki bulunmaktadır $(r \neq 0)$

H2: Mayıs 2020'de bağımlı ve bağımsız değişken setleri arasında ilişki bulunmaktadır $(r \neq 0)$

$H_{3}$ : Ekim 2020'de bağımlı ve bağımsız değişken setleri arasında ilişki bulunmaktadır ( $\left.r \neq 0\right)$ şeklinde oluşturulmuştur.

\section{Araştırmanın Bulguları}

Araştırmanın boylamsal yapısı gereği Şubat, Mayıs, Ekim 2020 aylarında tekrarlı ölçüm yapılmış olması ve kanonik korelasyon analizinin fazla sayıda çıktısı olması nedeniyle araştırma bulguları özetlenerek raporlanmıştır. Bu nedenle Şubat, Mayıs ve Ekim aylarına ait bağımsız ve bağımlı değişkenler setinde korelasyon katsayıları sunulduktan sonra söz konusu aylara ilişkin kanonik yükleri, fazlalık indeksini ve kanonik korelasyon katsayısını içeren kanonik modeller raporlanmış ve hipotez testleri gerçekleştirilmiştir.

Tablo 4: Bağımsız ve Bağımlı Değişkenler Setinde Korelasyon Katsayıları (Şubat)

\begin{tabular}{rcc}
\hline & Dünya sıralaması & Türkiye sıralaması \\
\cline { 2 - 3 } Sayfa hızı &,- 674 &,- 680 \\
Sayfa açılma süresi &, 517 &, 509 \\
Sayfa boyutu &, 441 &, 431 \\
\hline
\end{tabular}

Tablo 4'te 2020 Şubat ayına ait bağımsız değişkenler setinde yer alan web sitesi sayfa hızı, sayfa açılma süresi, sayfa boyutu ile bağımlı değişkenler setinde yer alan dünya sıralaması ve Türkiye sıralaması değişkenleri arasındaki korelasyonlar gösterilmiştir. Buna göre sayfa hızı ile dünya sıralaması $(-, 674)$ ve Türkiye sıralaması $(-, 680)$ arasında orta düzeyde negatif bir ilişki bulunurken sayfa açılma süresi ve sayfa boyutu ile dünya sıralaması (sırasıyla ,517 ve ,441) ve Türkiye sıralaması (sırasıyla ,509 ve 431 ) arasında orta düzeyde pozitif bir ilişki bulunmaktadır. 
Tablo 5: Bağımsız ve Bağımlı Değişkenler Setinde Korelasyon Katsayıları (Mayıs)

\begin{tabular}{rrrrccc}
\hline & $\begin{array}{c}\text { Dünya sırala- } \\
\text { ması }\end{array}$ & $\begin{array}{c}\text { Türkiye sıra- } \\
\text { laması }\end{array}$ & $\begin{array}{c}\text { Ziyaretçi } \\
\text { sayısı }\end{array}$ & $\begin{array}{c}\text { Geçirilen or- } \\
\text { talama süre }\end{array}$ & $\begin{array}{c}\text { Ziyaret başına gö- } \\
\text { rüntülenen sayfa } \\
\text { sayısı }\end{array}$ & $\begin{array}{c}\text { Siteden } \\
\text { hemen ay- } \\
\text { rılma oranı }\end{array}$ \\
\cline { 2 - 7 } Domain yaşı &,- 312 &,- 319 &, 489 &, 123 &, 226 &,- 237 \\
Referans sosyal medya &,- 126 &,- 225 &,- 241 &, 401 &, 210 &,- 177 \\
Sayfa hızı &,- 526 &,- 510 &,- 111 &, 457 &, 249 &,- 231 \\
Sayfa açılma süresi &, 221 &, 227 &,- 245 &,- 047 &, 054 &,- 385 \\
Sayfa boyutu &, 337 &, 319 &, 003 &,- 397 &,- 170 &, 027 \\
\hline
\end{tabular}

Tablo 5'te 2020 Mayıs ayına ait bağımsız ve bağımlı değişkenler setlerinin korelasyonları gösterilmiştir. Buna göre domain yaşı ile ziyaretçi sayısı $(489)$ ve referans sosyal medya ile geçirilen ortalama süre $(, 401)$ arasında orta düzeyde pozitif bir ilişki bulunmaktadır. Sayfa hızı ile dünya sıralaması $(-, 526)$ ve Türkiye sıralaması $(-, 510)$ arasında ise orta düzeyde negatif bir ilişki bulunmaktadır. Sayfa hızı ile geçirilen ortalama süre $(457)$ arasında ise orta düzeyde pozitif bir ilişki bulunmaktadır.

Tablo 6: Bağımsız ve Bağımlı Değişkenler Setinde Korelasyon Katsayıları (Ekim)

\begin{tabular}{|c|c|c|c|c|}
\hline & $\begin{array}{c}\text { Dünya sırala- } \\
\text { ması }\end{array}$ & $\begin{array}{c}\text { Türkiye sırala- } \\
\text { ması }\end{array}$ & Geçirilen ortalama süre & $\begin{array}{c}\text { Siteden hemen ay- } \\
\text { rılma oranı }\end{array}$ \\
\hline Domain yaşı &,- 503 &,- 504 & ,366 &,- 497 \\
\hline Siteye giriş kaynakları &, 505 & ,508 &,- 472 & ,604 \\
\hline Referans sosyal medya & 307 & ,246 &,- 305 & 397 \\
\hline Sayfa açılma süresi &, 546 & ,566 &,- 563 & ,456 \\
\hline
\end{tabular}

Tablo 6' da 2020 Ekim ayına ait bağımsız ve bağımlı değişkenler setlerinin korelasyonları gösterilmiştir. Buna göre domain yaşı ile dünya sıralaması $(-, 503)$, Türkiye sıralaması $(-, 504)$ ve siteden hemen ayrılma oranı $(-, 497)$ arasında; siteye giriş kaynakları ile geçirilen ortalama süre (,472) arasında; sayfa açılma süresi ile geçirilen ortalama süre $(-, 563)$ arasında orta düzeyde negatif bir ilişki bulunmaktadır. Ayrıca siteye giriş kaynakları ile dünya sıralaması $(, 505)$, Türkiye sıralaması $(, 508)$ ve siteden hemen ayrılma oranı $(, 604)$ arasında; sayfa açılma süresi ile dünya sıralaması (,546), Türkiye sıralaması $(, 566)$ ve siteden hemen ayrılma oranı $(, 456)$ arasında orta düzeyde pozitif bir ilişki bulunmaktadır. 
Tablo 7: Kanonik Modeller (Şubat-Mayıs-Ekim 2020)

\begin{tabular}{|c|c|c|c|c|c|c|}
\hline \multirow[b]{2}{*}{ Bağımsız Değişkenler Seti } & \multicolumn{2}{|c|}{ Şubat } & \multicolumn{2}{|c|}{ Mayıs } & \multicolumn{2}{|c|}{ Ekim } \\
\hline & $\begin{array}{c}\text { Kanonik } \\
\text { Yük }\end{array}$ & $\begin{array}{l}\text { Fazla- } \\
\text { lık İn- } \\
\text { deksi }\end{array}$ & $\begin{array}{c}\text { Kanonik } \\
\text { Yük }\end{array}$ & $\begin{array}{l}\text { Fazla- } \\
\text { lık İn- } \\
\text { deksi }\end{array}$ & $\begin{array}{c}\text { Kanonik } \\
\text { Yük }\end{array}$ & $\begin{array}{l}\text { Fazla- } \\
\text { lık İn- } \\
\text { deksi }\end{array}$ \\
\hline Domain yaşı & & \multirow{6}{*}{ 292 } & ,383 & \multirow{6}{*}{ 136 } & ,450 & \multirow{6}{*}{,230 } \\
\hline Siteye giriş kaynakları & & & & &,- 484 & \\
\hline Referans sosyal medya & & & 620 & &,- 696 & \\
\hline Sayfa hızı & ,835 & & 025 & & & \\
\hline Sayfa açılma süresi &,- 607 & &,- 500 & &,- 569 & \\
\hline Sayfa boyutu &,- 510 & &,- 103 & & & \\
\hline \multicolumn{7}{|l|}{ Bağımlı Değişkenler Seti } \\
\hline Dünya sıralaması &,- 975 & \multirow{6}{*}{,640 } &,- 357 & \multirow{6}{*}{,091 } &,- 784 & \multirow{6}{*}{,459 } \\
\hline Türkiye sıralaması &,- 993 & &,- 453 & &,- 746 & \\
\hline Geçirilen ortalama süre & & & ,374 & & ,808 & \\
\hline Siteden hemen ayrılma oranı & & &,- 066 & &,- 815 & \\
\hline Ziyaretçi sayısı & & & 297 & & & \\
\hline Ziyaret başına görüntülenen sayfa sayısı & & & ,265 & & & \\
\hline Kanonik (Setler arası) Korelasyon & \multicolumn{2}{|c|}{813} & \multicolumn{2}{|c|}{,927 } & \multicolumn{2}{|c|}{,859 } \\
\hline Wilk's $\lambda$ & \multicolumn{2}{|c|}{,316 } & \multicolumn{2}{|c|}{,005 } & \multicolumn{2}{|c|}{, 067} \\
\hline Anlamlılık ( $p$ değeri) & \multicolumn{2}{|c|}{,032 } & \multicolumn{2}{|c|}{,024 } & \multicolumn{2}{|c|}{028} \\
\hline
\end{tabular}

Tablo 7'de kanonik modeller ve hipotez testleri özetlenmiştir. Yapılan analizler sonucunda Şubat, Mayıs ve Ekim ayları için birinci kanonik fonksiyonlar (varyeteler) istatistiksel olarak anlamlı olduğundan sadece bunlar yorumlanmıştır. Buna göre tabloda yer alan tüm kanonik modeller $p<=, 05$ olduğu için anlamlıdır ve bağımsız değişken seti ile bağımlı değişken seti arasındaki kanonik (setler arası) korelasyon katsayısı sıfırdan farklıdır. Böylelikle 2020 Şubat, Mayıs ve Ekim aylarına ait hipotezler kabul edilmektedir. Tabloda kanonik modele katkı sağlamayan ve kanonik katsayısı ve kanonik yükü uygun olmayan değişkenlere ait veriler gösterilmemektedir. Sadece anlamlı modelde yer alan değişkenlere ilişkin katsayılar ve yükler raporlanmıştır.

2020 Şubat ayı için geçerli olan kanonik model istatistiki olarak anlamlıdır (Wilk's $\lambda=, 316$ ve $p=$,032). Bağımsız değişkenler seti ile bağımlı değişkenler seti arasında güçlü bir ilişki bulunmaktadır ve ilgili kanonik (setler arası) korelasyon katsayısı ,813 olarak hesaplanmıştır. 2020 Şubat ayı için bağımsız değişkenler setinde sırasıyla sayfa hızı, sayfa açılma süresi ve sayfa boyutu değişkenleri bulunmaktadır, ilgili değişkenlere ait kanonik yükler sırasıyla ,835; -,607; -,510 olarak hesaplanmıştır. Bağımsız değişkenler setindeki varyansın bağımlı değiş̧kenler seti tarafından açıklanma oranı \%29,2' dir (Fazlalık indeksi = ,292). Diğer taraftan 2020 Şubat ayı için bağımlı değişkenler setinde sadece dünya sıralaması $(-, 975)$ ve Türkiye sıralaması $(-, 993)$ yer almaktadır. Bağımlı değişkenler setindeki varyansın bağımsız değişkenler seti tarafından açıklanma oranı \%64'tür.

2020 Şubat ayına ait kanonik modelin daha az değişkenli yapısına rağmen 2020 Mayıs ayına ait kanonik modelde daha fazla değişken yer almaktadır. 2020 Mayıs ayına ait kanonik model istatistiki olarak anlamlıdır (Wilk's $\lambda=, 005$ ve $p=, 024$ ). Bağımsız değişkenler seti ile bağımlı değişkenler seti arasında güçlü bir ilişki bulunmaktadır (kanonik korelasyon katsayısı $(r)=, 927)$. 2020 Mayıs ayında bağımsız değişkenler setinde domain yaşı (,383), referans sosyal medya 
$(, 620)$, sayfa hızı $(, 025)$, sayfa açılma süresi $(-, 500)$ ve sayfa boyutu $(-, 103)$ değişkenleri bulunmaktadır. Bağımsız değişkenler setindeki değişimin bağımlı değişkenler seti tarafından açıklanma oranı \%13,6'dır. Diğer taraftan, bağımlı değişkenler setinde dünya sıralaması (-,357), Türkiye sıralaması $(-, 453)$, geçirilen ortalama süre $(, 374)$, siteden ayrılma oranı $(-, 066)$, ziyaretçi sayısı $($,297) ve ziyaret başına görüntülenen sayfa sayısı $(, 265)$ yer almaktadır. Bağımlı değişkenler setindeki değişimin bağımsız değişkenler seti tarafından açıklanma oranı \%9,1'dir.

2020 Ekim ayına ait kanonik model Şubat ve Mayıs aylarına kıyasla daha farklı bir desen ortaya çıkarmaktadır. Gerek modelde yer alan değişkenler gerekse de değişken sayısı itibariyle diğer aylardan farklılık göstermektedir. Diğer aylarda olduğu gibi Ekim ayına ait kanonik model istatistiki olarak anlamlıdır (Wilk's $\lambda=, 067$ ve $p=, 028$ ). Bağımsız değişkenler seti ile bağımlı değişkenler seti arasında güçlü bir ilişki bulunmaktadır $(r=$,859). 2020 Ekim ayı için bağımsız değişkenler setinde domain yaşı $(, 450)$, siteye giriş kaynakları $(-, 484)$, referans sosyal medya (,696) ve sayfa açılma süresi $(-, 569)$ değişkenleri bulunmaktadır. Bağımsız değiş̧kenler setindeki varyasın bağımlı değişkenler seti tarafından açıklanma oranı \%23'tür. Öte yandan, 2020 Ekim ayı için bağımlı değişkenler setinde dünya sıralaması $(-, 784)$, Türkiye sıralaması $(-, 746)$, geçirilen ortalama süre $(, 808)$ ve siteden hemen ayrılma oranı $(-, 815)$ yer almaktadır. Bağımlı değişkenler setindeki değişimin bağımsız değişkenler seti tarafından açıklanma oranı \%45,9'dur.

\section{Sonuç, Öneriler ve Kısıtlar}

Internet kullanımının artmasına paralel olarak dünya genelinde e-ticaret kullanımı artmaktadır. We are Social'ın yayınlamış olduğu rapora göre dünya genelindeki aktif internet kullanıcı sayısı 4,54 milyardır ve bunların 3,47 milyarı da aktif bir şekilde e-ticaret web sitelerinden alışveriş yapmaktadır (We are Social, 2020). Özellikle Covid-19 pandemi döneminde müşterilerin fiziksel temastan kaçınması alışveriş dâhil birçok faaliyeti internet ortamına taşımıştır. Bu durum müşterilerin ve işletmelerin davranışlarını değiştirmiş ve e-ticareti kullanımını arttırmıştır. Böylece e-ticaret pazaryeri web sitelerinin de önemi artmıştır. Bu bağlamda çalışma kapsamında Covid-19 pandemi döneminde (Şubat-Mayıs-Ekim 2020) e-ticaret pazaryeri web sitelerinin teknik özellikleri, web sitelerine giriş kaynakları ve referans sosyal medya ile web sitesi kullanım istatistikleri arasındaki ilişki ele alınmıştır. Böylelikle, Covid-19 pandemisinin süreç boyunca önerilen ilişkilere etkisi de boylamsal olarak ele alınabilmektedir.

Geliştirilen kanonik modellerde yer alan değişkenlerin ve ilgili katsayıların aylara göre önemli ölçüde farklılaştığı görülmektedir. 2020 Şubat ayında, pandemi öncesi dönemde sade bir yapıda bulunan ve sadece e-ticaret pazaryeri web sitesinin teknik özellikleri ile web sitesinin dünya ve Türkiye sıralaması arasında ilişki bulunmaktadır. E-ticaret pazaryeri web sitelerinin hızlı açılıyor olması, açılma süresinin kısalması ve sayfa boyutunun azalması ilgili web sitesinin dünya ve Türkiye sıralamasını yükseltmekte ve olumlu katkı yapmaktadır. Başka bir ifadeyle, pandemi öncesi süreç açısından e-ticaret pazaryeri web sitelerinin başarı ve performansları daha çok web sitesi teknik özellikleriyle ilişkilidir. Pandemi öncesi süreçte bağımsız ve bağımlı değişkenler arasındaki ilişki önemli bir sadelik sergilemektedir.

Diğer taraftan, dünya genelinde olduğu gibi ülkemizde de pandeminin ilk zirveyi görmesine yakın bir zaman olan 2020 Mayıs ayında önerilen model daha kompleks bir yapı sergilemektedir. Bu durumda e-ticaret pazaryeri web sitelerinin teknik özellikleri kadar web sitesi açısından referans sosyal medya değişkeni de modele önemli bir etkiyle dâhil olmuştur. Web sitesi teknik özelliklerinin etkisi ise Şubat ayına kıyasla kısmen azalmıştır. Bu durumda e-ticaret web sitelerinin başarı ve performansı açısından sosyal medya sitelerinden olan yönlendirmelerin ve refe- 
ransların büyük etkiye sahip olduğu söylenebilir. Bu süreçte Covid-19 pandemisiyle ilgili il özelinde ve ülke genelinde çeşitli kısıtlayıcı uygulamaların söz konusu olması tüketicileri daha çok sosyal medya üzerinden e-ticarete yönlendirmiş olduğu ifade edilebilir. Diğer yandan, e-ticaret pazaryeri web sitelerinin başarı ve performans kriterleri açısından da pek çok değişken modelde yerini almıştır. Bu durumda sadece dünya ve Türkiye genelindeki bilinirlik/kullanım sıralamasının ötesinde, web sitesinin ziyaretçi sayısı, web sitesinde geçirilen ortalama süre, ziyaret başına görüntülenen sayfa sayısı ve siteden hemen ayrılma oranı değişkenleri önemli bir yer edinmiştir. Buna göre Mayıs ayında tüketiciler daha çok daha eski olan e-ticaret pazaryerlerini tercih etmişlerdir. Sosyal medyanın etkisi ise web sitelerinde geçirilen ortalama süre üzerinde etkili olmuştur. Sosyal medya platformlarının referansıyla e-ticaret pazaryerlerini ziyaret eden tüketiciler ilgili pazaryeri web sitesine daha çok zaman geçirmiştir. Benzer biçimde sayfanın açılma hızı ve boyutunun da e-ticaret pazaryeri web sitesinde geçirilen ortalama süreyi olumlu etkilediği ifade edilebilir.

Sadece ekonomik hayatta değil, genel olarak pek çok alanda belirsizliğin devam etmekte olduğu 2020 Ekim ayında ise Şubat ve Mayıs ayına kıyasla çok daha farklı bir tablo ortaya çıkmaktadır. Buna göre Ekim ayında e-ticaret pazaryeri web sitelerine ait değişkenler gerek Şubat ayındaki sade ilişki yapısı gerekse de Mayıs ayındaki karmaşadan farklı bir durum sergilemektedir. Bu ayda e-ticaret pazaryeri web sitelerinin teknik özelliklerinin etkisi azalmaya devam etmiş, bunun yerine Mayıs ayındaki gibi referans sosyal medya etkisini sürdürmüş ve siteye giriş kaynakları web sitelerinin başarı ve performansında önemli etkiye sahip olmuştur. Bu durumda eticaret pazaryeri web sitelerinin teknik özelliklerinden ziyade web sitesine giriş yöntemleri ile sosyal medyanın daha fazla etkiye sahip olduğu görülmektedir. E-ticaret pazaryeri web sitelerinin e-posta, reklam, arama sonuçları, doğrudan web sitesi reklamları vb. yöntemler ile sosyal medya platformlarını kullanmalarının e-ticaret pazaryeri web sitelerinin kullanım istatistiklerine olumlu etkisi olduğu görülmektedir. Özellikle sosyal medya referansları e-ticaret pazaryeri web sitelerinin performansına önemli katkı sağlamaktadır. Bu durum pandemi öncesi süreç olan Şubat ayına kıyasla oldukça farklı bir yapı sergilemektedir. Web sitesi teknik özellikleri arasında eticaret pazaryerinin eski ve bilinir olması ile sayfalarının hızlı açılması önemli değişkenlerdir. Pandeminin ilerleyen sürecinde tüketiciler daha eski olan ve daha bilinir olan e-ticaret pazaryerlerini tercih etmektedir. E-ticaret pazaryeri web sitelerinin dünya ve Türkiye'deki sıralaması açısından en önemli katkıyı eski ve bilinir olması, siteye girişte çeşitli kaynakların kullanımı ve sayfa açılma süresi sağlamaktadır. Web sitesinde geçirilen ortalama süreyi en çok siteye girişte çeşitli kaynakların kullanımı ve azalan sayfa açılma süresi etkilemektedir.

E-ticaret pazaryeri web sitelerinin pandemi sürecindeki performansına ve kullanımına aylara göre artan oranda sosyal medya platformlarının referans olma ve yönlendirici etkileri önemli katkı sağlamaktadır. E-ticaretin giderek yaygınlaşmasının yanında tüketicilerin hali hazırda önemli oranda sosyal medya platformlarında uzun zaman geçirmeleri nedeniyle bu platformlar üzerinden e-ticaret pazaryeri web sitelerinin reklam ve çeşitli tanıtıcı bilgilerinin bulunması önemli bir strateji olarak uygulanmaktadır. Bunda Covid-19 pandemi sürecinde artan çeşitli kısıtlamalar nedeniyle de tüketicilerin sosyal medya platformlarında daha uzun zaman geçirmek zorunda olması önemli bir etkendir. Sosyal medya haricinde e-ticaret pazaryeri web siteleri açısından en önemli değişken web sitelerine ait sayfaların açılma süresidir. Buna internet bağlantı hızı vb. diğer kontrol edilemeyen durumlar da eklendiğinde web sitesi sayfalarının açılma süresinin önemi bir kez daha anlaşılmaktadır. Sosyal medyadan farklı olarak web sitelerinin sayfa açılma süresi teknik özelliği pandemi sürecini kapsayan Şubat, Mayıs ve Ekim ayları boyunca en 
önemli değişkenlerin başında gelmektedir. Ayrıca e-ticaret pazaryeri web sitesinin eski ve bilinir olması da performans ve kullanım istatistiği açısından önemli bir yere sahiptir.

Çalışmada bağımlı değişkenler seti olarak adlandırılan web sitesi kullanım istatistiklerinin aynı zamanda web sitesi performans değişkenleri olarak da ele alınması mümkündür. Buna göre pandemi öncesi Şubat ayı içerisinde web sitesinin bilinirliği, sıralaması vb. ziyaretçi sayısıyla ilgili değişkenler ön planda iken diğer aylarda bu durum değişim göstermektedir. Buna karşın, web sitesinde geçirilen ortalama süre aylara göre artan önemli bir değişken haline gelmiştir. Böylelikle e-ticaret pazaryeri web sitelerinin bilinirlik ve sıralama vb. ziyaretçi sayısının yanı sıra web sitesinde geçirilen ortalama süreyi de ele alacak plan ve stratejiler geliştirmesi işletmeler açısından oldukça yararlı olacaktır. Bu performans kriterlerine ise en çok katkıyı web sitesinin eski ve bilinir olması, sosyal medya platformlarının kullanımı ve sayfa açılma süresi katkı sağlamaktadır. Tüm bu nedenlerle genel olarak e-ticaret gerçekleştiren işletmelerin, özelde ise e-ticaret pazaryeri web sitelerini kullanan ve ilk defa kullanacak işletmelerin eski ve bilinir e-ticaret pazaryerlerini tercih etmeleri, e-ticaret siteleri ile sosyal medya entegrasyonlarını başarılı ve etkili bir biçimde sağlamaları ve başta sayfa açılma süresi olmak üzere çeşitli web sitesi teknik özelliklerine önem ve ağırlık vermeleri önerilmektedir. Tüm bunların yanı sıra analizlerde ortaya konulduğu şekliyle sadece ziyaretçi sayısını temel alan sıralamaların ötesinde ziyaretçilerin web sitesinde geçirmekte olduğu ortalama süreyi arttırmayı hedefleyen çalışmalar ve planlar yürütmeleri performanslarına olumlu katkı sağlayacaktır. Bu durum büyük belirsizlikler barındıran covid19 pandemisinin farklı zamanlarında ortaya konulan modeller sonucunda elde edilen ve test edilmiş önemli stratejiler olup, benzer belirsiz diğer zamanlarda da etkili olabileceği öne sürebilir.

Covid-19 pandemi döneminde e-ticaret kullanımının arttığı ve tüketici davranışlarının önemli derecede değiştiği bilinmektedir. Bu bağlamda Şubat-Mayıs-Ekim 2020 aylarında e-ticaret pazaryeri web sitelerine ait teknik özellikler, kullanım istatistikleri, siteye giriş kaynakları ve web siteleri için yapılan aramalarda önemli değişiklikler meydana gelmiştir. Elde edilen bulgularda farklı aylarda web sitelerine ait farklı değişkenlerin birbirini etkilediği ve ön plana çıktığı görülmektedir. Bu nedenle çalışma Covid-19 pandemisinin farklı zamanlarında e-ticaret web sitelerine ait hangi özelliklerin ön plana çıktığı ve hangi özelliklerin birbirini nasıl ve ne yönde etkilediğini ortaya koyması bakımından önem arz etmektedir. Ayrıca literatür incelendiğinde eticaret web sitelerine ait teknik özellikler, kullanım istatistikleri, web siteye giriş kaynakları ve web site için yapılan aramalar ile ilgili birçok çalışma bulunmasına rağmen bu çalışmalar pandemi öncesini kapsamakta ve daha çok tüketici algısına odaklanmaktadır. Pandemi döneminde e-ticaret ile ilgili yapılan çalışmaların büyük oranda tüketici davranışlarındaki değişime odaklı olması bu çalışmayı e-ticaret web sitelerine ait ikincil verilere dayalı olması yönüyle ön plana çıkarmaktadır. Tüm bu yönleriyle çalışma literatüre ve iş dünyasına önemli katkılar sunmaktadır.

Çalışmanın artıları ve güçlü yönleri yanında bazı kısıtları da bulunmaktadır. Zaman açısından Şubat, Mayıs ve Ekim ayı bir kısıt oluşturmaktadır. Pandeminin başlamasıyla birlikte aylık ölçümlerin kullanılacağı farklı panel verileri ve modellerinin test edilmesinin daha kapsayıcı sonuçlar ortaya koyacağı söylenebilir. Ayrıca çalışma ülkemizde en çok tercih edilen 16 e-ticaret pazaryeri platformuna odaklanmıştır. Benzer bir çalışma dünya genelinde de uygulanabilir. Araştırma verileri Similarweb ve Gtmetrix'ten elde edilmiştir, benzer istatistikler sunan diğer data sitelerinden de veriler elde edilerek çalışma değişkenleri de genişletilebilir. Bu bağlamda gelecek çaıışmaların daha fazla ve daha farklı e-ticaret web sitesin dâhil edilerek, farklı aylara ait verilerle 
yapılması çalışmanın bulgularını ve sonuçlarını güçlendirecektir. Bununla birlikte gelecek çalışmaların özellikle pandemi öncesi, pandemi süreci ve pandemi sonrası dönemlere ait verilerle yinelenmesi pandemi döneminin pandemi öncesi ve sonrası dönemden farkını ve değişimini ortaya koyması açısından etkili olacaktır. Son olarak, çalışmanın verileri ikincil verilerden oluşmaktadır. Tüketici davranışlarını da yansıtacak birincil verilere ait değişkenlerin modele dâhil edilmesi alana önemli katkı sağlayacaktır. 


\section{Kaynakça}

Albuquerque, A. B., \& Belchior, A. D. (2002). E-commerce website quality evaluation. Conference Proceedings of the EUROMICRO, (February 2002), 294-300.

Almousa, M. (2013). Barriers to e-commerce adoption: Consumers' perspectives from a developing country. iBusiness, 05(02), 65-71.

Barkatullah, A. H., \& Djumadi. (2018). Does self-regulation provide legal protection and security to e-commerce consumers? Electronic Commerce Research and Applications, 30(May), 94-101.

Bhatti, A., Akram, H., Basit, H. M., Khan, A. U., Naqvi, S. M. Raza, \& Bilal, M. (2020). E-commerce trends during COVID19 Pandemic. International Journal of Future Generation Communication and Networking, 13(2), 1449-1452.

Bilal, M., Yu, Z., Song, S., \& Wang, C. (2019). Evaluate accessibility and usability issues of particular China and Pakistan government websites. 2019 2nd International Conference on Artificial Intelligence and Big Data, ICAIBD 2019, 316322.

Blake, T., Nosko, C., \& Tadelis, S. (2015). Consumer heterogeneity and paid search effectiveness: A large-scale field experiment. Econometrica, 83(1), 155-174.

Bodkin, C. D., \& Perry, M. (2004). Goods retailers and service providers : comparative analysis of web site marketing communications. 11, 19-29.

Boulte, A. (2020). Mobil sitenizi hızlandırmak karlılığınızı nasıl artırır ?. https://www.thinkwithgoogle.com/intl/trtr/pazarlama-stratejileri/uygulama-ve-mobil/mobile-sayfa-hizi-verisi/. Erişim tarihi: 16.12.2020.

Carmona, C. J., Ramírez-Gallego, S., Torres, F., Bernal, E., Del Jesus, M. J., \& García, S. (2012). Web usage mining to improve the design of an e-commerce website: OrOliveSur.com. Expert Systems with Applications, 39(12), 1124311249.

Cao, M., Zhang, Q., Seydel, J., Cao, M., Zhang, Q., \& Seydel, J. (2005). B2C e-commerce web site quality : an empirical examination B2C e-commerce web site quality: an empirical examination. Industrial Management and Data System Emerald Article, 105(5), 645-661.

Chakraborty, R., Lee, J., Bagchi-sen, S., Upadhyaya, S., \& Rao, H. R. (2016). Online shopping intention in the context of data breach in online retail stores : An examination of older and younger adults. Decision Support Systems, 83, 4756.

Chaudhary, H. (2020). Analyzing the paradigm shift of consumer behavior towards e-commerce during pandemic lockdown. Available at SSRN 3664668.

Chen, J. C. V., Lin, C., Wu, Y. S., (2013). Electronic word of mouth: The moderating roles of product involvement and brand image, Proceeding of 2013 International Conference on Technology Innovation and Industrial Management, Phuket, Thailand, 29- 47.

Chen, S., \& Lin, C. (2019). Technological Forecasting \& Social Change Understanding the effect of social media marketing activities: The mediation of social identification, perceived value, and satisfaction. Technological Forecasting \& Social Change, 140(November 2018), 22-32.

Chong, A. Y. L., Lacka, E., Boying, L., \& Chan, H. K. (2018). The role of social media in enhancing guanxi and perceived effectiveness of E-commerce institutional mechanisms in online marketplace. Information and Management, 55(5), 621-632.

Choshin, M., \& Ghaffari, A. (2017). An investigation of the impact of effective factors on the success of e-commerce in small- and medium-sized companies. Computers in Human Behavior, 66, 67-74.

Choudhury, M. M., \& Choudhury, A. M. (2010). Identification of the characteristics of e-commerce websites. Webology, $7(1), 1-10$

Chow, D. C. K. (2020). Alibaba, amazon, and counterfeiting in the age of the internet. Northwestern Journal of International Law and Business, 40(2), 157-202.

Çelik, T. (2019). Elektronik ticaret ve rekabet hukuku kapsamında çok taraflı pazar yerleri, Maltepe Üniversitesi Sosyal Bilimler Enstitüsü. Yayımlanmış Yüksek Lisans Tezi. İstanbul.

Çemrek, F. (2012). Türkiye'deki illerin gelir ve refah düzeyi değişkenleri arasındaki ilişkinin kanonik korelasyon analizi ile incelenmesi. Eskişehir Osmangazi Üniversitesi iiBF Dergisi, 7(2), 197-215.

Danaher, P. J., Mullarkey, G. W., \& Essegaier, S. (2006). Factors affecting web site visit duration: A cross-domain analysis. Journal of Marketing Research, 43(2), 182-194.

Dhar, J., \& Jha, A. K. (2014). Analyzing social media engagement and its effect on online product purchase decision 
behavior. Journal of Human Behavior in the Social Environment, 24(7), 791-798.

Dias, J. P., \& Ferreira, H. S. (2017). Automating the extraction of static content and dynamic behaviour from ecommerce websites. Procedia Computer Science, 109, 297-304.

Duygun, A., \& Şen, E. (2020). Evaluation of consumer purchasing behaviors in the COVID-19 pandemic period in the context of Maslow's hierarchy of needs. Pazarlama Teorisi ve Uygulamaları Dergis, 6(1), 45-68.

Egger, S., Hobfeld, T., Schatz, R., \& Fiedler, M. (2012). Waiting times in quality of experience for Web based services. In 4 th International workshop on quality of multimedia experience (QoMEX 2012). Yarra Valley, Australia

Egri, G., \& Bayrak, C. (2014). The role of search engine optimization on keeping the user on the site. Procedia-Procedia Computer Science, 36, 335-342.

Elisa, N. (2017). Usability, accessibility and web security assessment of E-government websites in Tanzania. International Journal of Computer Applications, 164(5), 42-48.

Fagan, J. C. (2014). The suitability of web analytics key performance indicators in the academic library environment. Journal of Academic Librarianship, 40(1), 25-34.

Gangeshwer, D. K. (2013). E-Commerce or internet marketing: A business review from Indian context. International Journal of $u$ - and e-Service, Science and Technology, 6(6), 187-194.

GTmetrix (2020). How fast does your website load? Find out with GTmetrix. https://gtmetrix.com/. Erişim tarihi: ŞubatMayıs-Ekim 2020.

Gupta, A. (2014). E-commerce: Role of e-commerce in today's business. International Journal of Computing and Corporate Research, 4(1), 1-8.

Güler, D. (2019). Web sitenize trafik çekmenin detaylı anlatımla 27 yolu. https://dogucanguler.com/web-sitenize-trafikcekmenin-detayli-anlatimla-27-yolu/. Erişim tarihi: 20.11.2020.

Günay, M. (2012). Domain Yaşının Önemi. https://www.mucahitgunay.com.tr/blog/domain-yasinin-onemi.html Erişim tarihi: 24.12.2020.

Hasan, L., Morris, A., \& Probets, S. (2009). Using google analytics to evaluate the usability of e-commerce sites. Lecture Notes in Computer Science (including subseries Lecture Notes in Artificial Intelligence and Lecture Notes in Bioinformatics), 5619 LNCS, 697-706.

Hasanat, M. W., Hoque, A., Shikha, F. A., \& Anwar, M. (2020). The impact of coronavirus ( Covid-19 ) on e-business in Malaysia. Asian Journal of Multidisciplinary Studies, 3(1), 85-90.

Heinen, J. (1996). Internet marketing practices. Information Management \& Computer Security, 4(5), 7-14.

Hsu, M. H., Chang, C. M., Chu, K. K., \& Lee, Y. J. (2014). Determinants of repurchase intention in online group-buying: The perspectives of DeLone \& McLean is success model and trust. Computers in Human Behavior, 36, 234-245.

İsayev, O., Nart, Ö. (2019). A'dan Z'ye e-ihracat, İstanbul, World Ecommerce Forum Yayınları.

İiler, Z. (2009). Elektronik ticaret ve pazarlama, ihracatta internet zamanı. Ankara: IGEME.

Kalaycı, Ş. (2006). SPSS Uygulamalı Çok Değişkenli Istatistik Teknikleri, 2. Baskı, Ankara: Asil Yayın Dağıtım.

Kiyea, C., \& Bolatito Yusuf, A. (2014). Usibility evaluation of some selected Nigerian universitie's websites. International Journal of Computer Applications, 104(3), 6-11.

Kotler, P., Kartajaya, H., and Setiawan, I. (2017). Marketing 4.0: Moving from traditional to digital. New Jersey: Jhon Wiley\&Son.

Kuşat, N. (2016). İşletmeden işletmeye (B2B) elektronik pazar yerleri ve gelişmekte olan ülkelerin dış ticaretinde uygulanabilirliği, Yönetim ve Ekonomi Dergisi, 23(3), 691-709.

Manhas, J. (2013). A study of factors affecting websites page loading speed for efficient web performance. International Journal of Computer Sciences and Engineering, 1(3), 32-35.

Marangoz, M. (2014). Internette pazarlama, İstanbul, Beta Yayıncllık.

Nicholas, D., Huntington, P., \& Williams, P. (2002). Evaluating metrics for comparing the use of web sites: A case study of two consumer health web sites. Journal of Information Science, 28(1), 63-75.

Niranjanamurthy, M., Kavyashree, N., \& Chahar, S. J. D. (2013). Analysis of e-commerce and m-Commerce: Advantages, limitations and security issues. International Journal of Advanced Research in Computer and Communication Engineering, 2(6), 2360-2370.

Nwokah, N.G. and Ntah, S.W. (2017) Website quality and online shopping of e-tail stores in Nigeria. Journal of Service Science and Management, 10, 497-517. 
Omidvar, A., M., Reza Mirabi, V., \& Shokry, N. (2011). Analyzing the impact of visitors on page views with Google Analytics. International journal of Web \& Semantic Technology, 2(1), 14-32.

Oypan, S. (2020). E-ticarette marka bilinirliği nasıl artırılır? https://www.ideasoft.com.tr/marka-bilinirligi-nasil-artirilir/. Erişim tarihi: 02.12.2020.

Özbek, A., Esmer, Y. (2019). Hazır giyim işletmelerinin e-pazar yeri kullanımlarının teknoloji kabul modeli ile incelenmesi. International Conferences on Social Science Research (ICONSR 2019), 26-30 August 2019 Prizren - Kosovo.

Pakkala, H., Presser, K., \& Christensen, T. (2012). Using Google Analytics to measure visitor statistics: The case of food composition websites. International Journal of Information Management, 32(6), 504-512.

Pantelimon, F., Georgescu, T., \& Posedaru, B.-Ş. (2020). The impact of mobile e-commerce on GDP: A comparative analysis between Romania and Germany and how Covid-19 influences the e-commerce activity worldwide. Informatica Economică vol., 24(2), 27-41.

Park, C., \& Lee, M., T. (2009). Information direction, website reputation and eWOM effect : A moderating role of product type. Journal of Business Research, 62(1), 61-67.

Plaza, B. (2011). Google Analytics for measuring website performance. Tourism Management, 32(3), 477-481.

Poulos, M., Korfiatis, N., \& Papavlassopoulos, S. (2020). Assessing stationarity in web analytics: A study of bounce rates. Expert Systems, 37(3), 1-13.

Rababah, O., \& Masoud, F. (2010). Key factors for developing a successful e-commerce website. Communications of the IBIMA, 2010, 1-9.

Rakhmawati, N. A., Ferlyando, V., Samopa, F., \& Astuti, H. M. (2017). A performance evaluation for assessing registered websites. Procedia Computer Science, 124, 714-720.

Rutz, O. J., Trusov, M., \& Bucklin, R. E. (2011). Modeling indirect effects of paid search advertising: Which keywords lead to more future visits? Marketing Science, 30(4), 646-665.

Similarweb, (2020a). Traffic overview. https://www.similarweb.com/. Erişim tarihi: Şubat-Mayıs-Ekim 2020.

Similarweb, (2020b). Top websites ranking. https://www.similarweb.com/top-websites/turkey/. Erişim tarihi: 09.02.2020.

Statista. (2020). Coronavirus impact on retail e-commerce website traffic worldwide as of June 2020, by average monthly visits. https://www.statista.com/statistics/1112595/covid-19-impact-retail-e-commerce-site-traffic-global/. Erişim tarihi: 10.12.2020.

Stratta, R., \& Voxlin, D. (2020). Perakendecilerin müşteri mobil deneyimi ve karlılığını iyileştirebilecek 5 yöntem. https://www.thinkwithgoogle.com/intl/tr-tr/pazarlama-stratejileri/uygulama-ve-mobil/mobile-deneyimi-gelistirin/. Erişim tarihi: 16.12.2020.

Sulova, S. (2019). A system for E-commerce website evaluation. International Multidisciplinary Scientific GeoConference Surveying Geology and Mining Ecology Management, SGEM, 19(2.1), 25-32.

Thompson, M. F., Tuzovic, S., \& Braun, C. (2019). Trustmarks: Strategies for exploiting their full potential in ecommerce. Business Horizons, 62(2), 237-247.

Toms, E. G., \& Taves, A. R. (2004). Measuring user perceptions of Web site reputation. Information Processing and Management, 40, 291-317.

Tran, L. T. T. (2020). Managing the effectiveness of e-commerce platforms in a pandemic. Journal of Retailing and Consumer Services, 58(April 2020), 102287.

Ünlükaplan, ì. (2009). Avrupa Birliği üyesi ülkelerde iktisadi kalkınma, rekabetçilik ve inovasyon ilişkilerinin kanonik korelasyon analizi ile belirlenmesi. Maliye Dergisi, (157), 235-250.

Wagner, N., Hassanein, K., \& Head, M. (2014). The impact of age on website usability. Computers in Human Behavior, 37, 270-282.

We Are Social. (2020). We are social global digital report 2020. https://wearesocial.com/digital-2020. Erişim tarihi: 26.12.2020

Yuan, Y., Guan, M., Zhou, Z., Kim, S., Cha, M., Jin, D., \& Li, Y. (2020). Disruption in the Chinese e-commerce during COVID-19. https://arxiv.org/abs/2009.14605. Erişim tarihi: 11.12.2020.

Zhang, P., von Dran, G. M., Small, R. V., \& Barcellos, S. (1999). Websites that satisfy users: A theoretical framework for web user interface design and evaluation. Proceedings of the Hawaii International Conference on System Sciences, (December 1998), 69. 


\section{Extended Summary}

\section{Dynamics of E-Commerce Marketplace Websites: Shift in Covid-19 Pandemic}

In recent years, internet and e-commerce usage are increasing with technological developments (Thompson et al., 2019: 239). According to the current report of We are Social, worldwide the number of active internet users is 4,54 billion, and 3,47 billion of them are actively shopping on e-commerce websites (We are social, 2020). Especially during the covid-19 pandemic period, many activities have been carried out on the internet, and customers who avoided physical contact have been more likely to shop on e-commerce websites (Tran, 2020: 1-2). Because e-commerce offers customers and businesses the opportunity to make easier, faster, higher quality, and less costly transactions (Gangeshwer, 2013:187; Niranjanamurthy et al., 2013: 2362-2364). Also, e-commerce enables to do all kinds of transactions in an electronic environment by abstaining from physical contact (Gupta, 2014: 1). In this context, to sustain and continue their activities businesses need to use e-commerce, which is spreading rapidly throughout the world (Kotler, 2017: 187).

Many studies conducted during the Covid-19 pandemic period have concluded that more than half of customers want to shop via e-commerce rather than physical stores (Bhatti et al., 2020: 1450). For this reason, traffic, visitors, and sales numbers of e-commerce websites have increased significantly (Statista, 2020). Thus, e-commerce marketplace websites that bring customers and sellers together and mediate transactions have become more substantial and widely used (Iyiler, 2009: 4; Tran, 2020: 1-2). With the increasing usage of e-commerce marketplace website technical features, such as domain age, page speed, page opening time and page size have become more important (Wagner vd., 2014: 270). Website technical features directly affect website awareness, website interaction, and website usage statistics. Because customers often want to shop from familiar websites (Park ve Lee, 2009: 62). This affects usage statistics such as the number of visitors, average time spent, pages per visit, bounce rate, world ranking, and Turkey ranking (Similarweb, 2020a). Besides, e-commerce marketplace websites need to attract customers and generate customer traffic to increase sales. In this context, traffic sources and searches for websites are important. Customers log in to e-commerce websites directly or with advertisements, social media platforms, email, and search engines (Similarweb, 2020a; Plaza, 2011: 477-480; Carmona et al., 2012: 11246; Pakkala et al., 2012: 506).

In this perspective, this study investigates how the technical characteristics of e-commerce marketplace websites such as domain age, page speed, page opening time, and page size; usage statistics such as the number of visitors, average time spent, pages per visits, bounce rate, world ranking, and Turkey ranking; traffic sources and searches for the web site are related to each other during different periods of the Covid-19 pandemic (February-May-October 2020). The sample consists of 16 e-commerce marketplace websites which are listed as the 100 most visited websites in Turkey (Similarweb, 2020b). The secondary data obtained from Smilarweb and GTmetrix were analyzed by canonical correlation analysis.

According to the findings, the variables and related coefficients in canonical models significantly differentiate by moths. In February 2020, only there is a relationship between technical features of e-commerce marketplace websites, Turkey, and world ranking. Increasing page speed, decreasing page opening time and page size raise and make a positive contribution to Turkey and the world ranking of e-commerce marketplace websites. In other words, in the prepandemic period, the success and performance of e-commerce marketplace websites are mostly related to the website's technical features. Also, in the pre-pandemic period, the relationship among independent and dependent variables displays an important simplicity.

In May 2020, close to the first peak of the pandemic, the proposed canonical model displays a more complex structure. In this case, the reference social media variable, as well as the website's technical features, had a significant impact on the model. Also, the effects of technical features of websites partially diminished compared to February 2020. Therefore, it can be said that referrals and references social media platforms have a great impact on the success and performance of websites. In this context, it can be stated that there was various restriction regarding Covid-19 pandemic through the country which led the customer to e-commerce via social media platforms. Besides, in this period, the variables of the number of visitors, average time spent, pages per visit, and bounce rate had a significant role in the model. Accordingly, consumers visited the older e-commerce marketplace websites in May. Also, social media had an impact on the average time spent on websites. Consumers who visited e-commerce marketplace websites with the reference of social media spent more time on relevant websites. Similarly, it can be stated that page size and speed have a positive impact on the average time spent.

In October 2020, when lots of uncertainty persist in many areas, very diverse picture emerges compared to February and May. In this month, the impact of the e-commerce marketplace website's technical features continued to diminish, instead, the effect of reference social media increased as in May. Also, traffic sources significantly affected 


\section{Eskişehir Osmangazi Üniversitesi İktisadi ve İdari Bilimler Fakültesi Dergisi}

the success and performance of the websites. In this case, reference social media and traffic sources have more effect rather than technical features of websites. Also, reference social media platforms and traffic sources positively effect websites usage statistics.

Among the website's technical features, old domain, familiarity, and fast opening pages are important variables. In the progress of pandemic, consumers prefer the older and familiar e-commerce marketplace websites. The most significant contribution in terms of world and Turkey ranking are old domain, familiarity, traffic sources, and opening time of websites. The average time spent on the website is mostly affected by the usage of various traffic sources and page opening time.

Consequently, different variables of websites in different months affect each other and stand out. For this reason, this study is important in terms of revealing which features of e-commerce websites stand out and how they affect each other in different times of the Covid-19 pandemic. Besides, when the literature was examined, there are lots of studies about technical features, usage statistics, sources, and searches of e-commerce marketplace websites, these studies were conducted before the Covid-19 pandemic period. Also, studies about e-commerce marketplace websites during the pandemic period mainly focus on changes in consumer behavior. Therefore, this study differs from others. For this reason, with all these aspects this study contributes to the business environment and literature. 